\section{The Potential of Using Plant Extracts as Green Corrosion Inhibitors in the Petroleum Industry}

Rudarsko-geološko-naftni zbornik

(The Mining-Geology-Petroleum Engineering Bulletin) UDC: $66.03: 622.8$

DOI: $10.17794 /$ rgn.2021.5.12

Original scientific paper

\author{
Katarina Žbulj'; Gordana Bilić'; Lidia Hrnčević'; Katarina Simon ${ }^{1}$ \\ ${ }^{1}$ University of Zagreb, Faculty of Mining, Geology and Petroleum Engineering, Pierottijeva 6, 10000 Zagreb
}

\begin{abstract}
In this paper, preliminary studies of ten (10) different plant extracts as potential corrosion inhibitors of carbon steel were examined. For each extract, the concentration range in which they show anti-corrosion action was first determined, and then the most effective concentration was determined for each extract. The tests were performed in a brine solution saturated with $\mathrm{CO}_{2}$ at room temperature. The aim of this study was to isolate extracts with high effectiveness and subsequent electrochemical and surface methods to determine the mechanism of inhibitory action. For this purpose, potentiodynamic polarization was performed with Tafel extrapolation. Among all the tested extracts, lady's mantle (92.17\%) and dandelion root (95.07\%) stood out with their inhibitor efficiencies (IE). Both tested extracts showed the behaviour of a mixed corrosion inhibitor with a dominant influence on the anode process.
\end{abstract}

Keywords:

$\mathrm{CO}_{2}$ corrosion; petroleum industry; carbon steel; plan extracts; green corrosion inhibitors

\section{Introduction}

From its very beginning, the petroleum industry has been facing the problem of corrosion since most of the equipment and pipelines in the petroleum industry are made of carbon steel. Through the process of oil and gas production, gathering, treatment and transportation, most of the process equipment and pipelines are made of carbon steel. Hydrocarbon production, depending on the type of the reservoir, also implies the production of a certain amount of brine and other impurities (dissolved gasses, sand, additives applied during production, etc.). With the production progress, i.e. the maturing of the production field, the share of the produced brine increases. As mentioned, the produced fluid can also contain, among other things, carbon dioxide $\left(\mathrm{CO}_{2}\right)$ and hydrogen sulphide $\left(\mathrm{H}_{2} \mathrm{~S}\right)$, which, dissolved in water (brine) cause corrosion and damage to the equipment.

In general, carbon steel is susceptible to corrosion. The steel most sensitive to corrosion is low carbon steel, which is mostly used in the petroleum industry. Low carbon steel is the carbon steel that contains less than $0.8 \%$ of carbon (Byars, 1999). Corrosion can be defined as the destruction of a material caused by an aggressive environment to which that material is exposed (Sastri, 2011). The consequences of corrosion in the petroleum industry could affect the environment (potential cause of a fluid spill) and also, due to equipment damage, but environ-

Corresponding author: Gordana Bilić

gordana.bilic@rgn.unizg.hr mental impacts also have a large economic impact. In 2014, in the IMPACT report (International Measures of Prevention, Application, and Economics of Corrosion Technologies Study) estimations of the global cost caused by corrosion were given. It was reported that the global costs due to corrosion are around $2.5 \times 10^{12} \mathrm{USD}$, which is about $3.4 \%$ of global Gross Domestic Product (GDP) (Koch et al., 2016).

In systems where water is present, electrochemical corrosion will occur. As already mentioned, flowlines are the most sensitive part of an oil and gas transportation system. Fluid, transported in flowlines, is not yet treated, it contains brine and impurities, such as carbon dioxide. Flowlines, gathering pipelines and waterlines are mostly made of low carbon steel, and that makes them susceptible to $\mathrm{CO}_{2}$ corrosion.

According to the data from CONCAWE (CONservation of Clean Air and Water in Europe) (Cech et al., 2021), during a five-year period (2015-2019), there were nine spill incidents caused by corrosion. Corrosion is the cause of the largest volume of spill, and has thus the biggest negative impact, with $233 \mathrm{~m}^{3}$ of average spillage in comparison with mechanical failure $\left(193 \mathrm{~m}^{3}\right.$ of average spillage) and operational causes $\left(17 \mathrm{~m}^{3}\right.$ of average spillage).

One of the ways to control the corrosion problem is with the application of corrosion inhibitors. Since there are some limitations in the usage of conventional corrosion inhibitors due to their toxicity, plant extracts, among other things, have been studied as so-called green corrosion inhibitors. These green corrosion inhibitors could 
Table 1: Plant extracts as green corrosion inhibitors tested in different media on different types of metals

\begin{tabular}{|c|c|c|c|c|}
\hline Metal & Corrosion medium & $\begin{array}{l}\text { Plant extract as corrosion } \\
\text { inhibitor }\end{array}$ & IE (\%) & Reference \\
\hline Mild steel & $\mathrm{HCl}$ & Artemisia pallens extract & $93-98$ & Garai et al., 2012 \\
\hline Carbon steel & $\mathrm{HCl}$ & Osmanthus fragrans extract leaf & 90 & Li et al., 2012 \\
\hline Carbon steel & $\mathrm{HCl}$ & Grape pomace extract & 97 & da Rocha et al., 2012 \\
\hline Mild steel & $\mathrm{HCl}$ & Lavandula dentata extract & 95 & Bouammali et al., 2013 \\
\hline Mild steel & $\mathrm{H}_{2} \mathrm{SO}_{4}$ & Argemone mexicana leaf extract & $80-92.5$ & Ji et al., 2013 \\
\hline Copper & $\mathrm{HCl}$ & Mangrove tannin & 87.6 & Shah et al., 2013 \\
\hline Copper & $\mathrm{H}_{2} \mathrm{SO}_{4}$ & Myrtus communis & $>85$ & Bozorg et al., 2014 \\
\hline Mild steel & $\mathrm{H}_{2} \mathrm{SO}_{4}$ & Marigold flower extract & 98.07 & Mourya et al., 2014 \\
\hline Carbon steel & $\mathrm{HCl}$ & Opuntia ficus indica extract & 91 & Flores-De los Rios et al., 2015 \\
\hline Carbon steel & $\begin{array}{l}\mathrm{H}_{2} \mathrm{SO}_{4} \\
\mathrm{HCl}\end{array}$ & Rice husk extract & 94.24 & Olawale et al., 2017 \\
\hline Carbon steel & $\begin{array}{l}\text { carbon dioxide saturated } \\
\text { chloride carbonate solution }\end{array}$ & Olive leaf extract & $>90$ & Pustaj, 2017 \\
\hline Mild steel & sodium chloride solution & Persian Liquorice extract & 98.8 & Alibakhshi et al., 2018 \\
\hline Mild steel & $\mathrm{HCl}$ & Coffee husk extract & 93.9 & Cordeiro et al., 2018 \\
\hline $\begin{array}{l}\text { Low carbon } \\
\text { steel }\end{array}$ & $\mathrm{HCl}$ & Prosopis juliflora plant extract & 91.5 & Fouda et al., 2018 \\
\hline $\begin{array}{l}\text { Low carbon } \\
\text { steel }\end{array}$ & $\mathrm{HCl}$ & Xanthium strumarium leaf extract & 94.82 & Khadom et al., 2018 \\
\hline X70 steel & $\mathrm{HCl}$ & Ginkgo leaf extract & 92.5 & Qiang et al., 2018 \\
\hline Mild steel & $\mathrm{H}_{2} \mathrm{SO}_{4}$ & Saraca ashoka extract & 95.48 & Saxena et al., 2018a \\
\hline Mild steel & $\mathrm{H}_{2} \mathrm{SO}_{4}$ & Sida cordifolia extract & 99 & Saxena et al., $2018 b$ \\
\hline Stainless steel & $\mathrm{HCl}$ & Taraxacum officinale leaf extract & 91.5 & Ugi et al., 2018 \\
\hline Copper & $\mathrm{HCl}$ & Alchemilla Vulgaris extract & $>95$ & Ahmed i Zhang, 2019 \\
\hline Mild steel & $3.5 \% \mathrm{NaCl}$ & Allium sativum (garlic) extract & 92 & Devikala et al., 2019a \\
\hline Mild steel & $3.5 \% \mathrm{NaCl}$ & Asafoetida extract & 90 & Devikala et al., 2019b \\
\hline Mild steel & $\mathrm{HCl}$ & Citrullus lanatus fruit extract & 91 & Dehghani et al., 2019 \\
\hline Mild steel & $\mathrm{HCl}$ & Carrot Peel extract & 88.08 & Saeed et al., 2020 \\
\hline Carbon steel & seawater & Taraxacum officinale extract & $>88.2$ & Deyab i Guibal, 2020 \\
\hline Mild steel & $\mathrm{HCl}$ & Paederia foetida leaf extract & 73.77 & Hossain et al., 2021 \\
\hline
\end{tabular}

have a great potential with their application in the petroleum industry.

Due to the maturity of the production fields and the obsolescence of the infrastructure, the corrosion problem is one of the major issues in the Croatian petroleum industry. The parts of the oil and gas gathering and transportation system that are most exposed to corrosive fluid are the flowlines, because the produced fluid, which is transported via flowlines, is still untreated, and the pipelines for extracted brine transport. Regarding the hydrocarbon gathering system pipeline leaks in Croatia, the data have been analysed for the period between 2010 and 2019. For the analysis, only fluid leaks with spill volume equal to or larger than $1 \mathrm{~m}^{3}$ were considered. The analysis has shown that corrosion was the main cause of pipeline leaks with an approximate share of $71 \%$ in total number of leaks. The analysed data indicated the highest frequency of leaks occurred in flowlines (INA d.d., 2021). The corrosion protection of these pipelines is usually done with the application of conventional organic corrosion inhibitors, which, due to their toxicity, have environmental limitations.

Alternatively, so-called green inhibitors, that can be, compared to conventional inhibitors, equally effective and are biodegradable and affordable, are being tested (Sastri, 2011; Pustaj, 2017; Goni i Mazumder, 2019). Due to their non-toxicity and biodegradability, the green corrosion inhibitors are environmentally acceptable (Montemor, 2016; Shehata et al., 2018; Popoola, 2019). Currently, the most researched green corrosion 
Table 2: Chemical composition of the steel sample (wt.\%)

\begin{tabular}{|l|l|l|l|l|l|l|l|l|l|}
\hline $\mathbf{C}$ & $\mathbf{S i}$ & $\mathbf{M n}$ & $\mathbf{P}$ & $\mathbf{S}$ & $\mathbf{C r}$ & $\mathbf{M o}$ & $\mathbf{N i}$ & $\mathbf{C u}$ & $\mathbf{F e}$ \\
\hline 0.32 & 0.25 & 1.38 & 0.016 & 0.009 & 0.24 & $<0.01$ & 0.02 & 0.01 & balance \\
\hline
\end{tabular}

inhibitors are plant extracts. In Table 1, some of the plant extracts already researched as green corrosion inhibitors are listed. As can be seen from Table 1, most research was conducted in an acidic corrosion medium, while the experiments in this paper refer to a nearly neutral medium with the presence of $\mathrm{CO}_{2}$.

In order to examine their effectiveness as corrosion inhibitors, extracts of some wild plants that can be found in Croatia were tested. For the overview of wild selfseeded plants, Grlics' encyclopaedia was used (Grlić, 1990). In the research, ten commercially available plant extracts were selected as potential carbon steel corrosion inhibitors in a simulated brine solution saturated with $\mathrm{CO}_{2}$. The extracts were selected based on their chemical composition, more specifically the active components they contain (flavonoids, saponins, polyphenols), which represent potential adsorption centres in adsorption on a metal surface. In this paper, the preliminary results of the laboratory research conducted as part of a doctoral thesis are given. The aim of the conducted laboratory research was to select certain plants based on their corrosion inhibition efficiency and to examine the possibility of their application as green corrosion inhibitors in the petroleum industry. Further research on the subject will include comprehensive laboratory research, which should include experiments in dynamic conditions, using specific electrochemical and surface methods, and biodegradability testing for determining the behaviour of the chosen plant extracts as corrosion inhibitors.

\section{Materials and methods}

The carbon steel sample used in the corrosion experiments is a steel sample that flowlines and brine pipelines are composed of. In Table 2, the chemical composition of the steel sample is shown. The chemical composition of the steel sample was determined by a GDS $850 \mathrm{~A}$, LECO spectrometer using the optical emission spectrometry method.

The brine used in the research was prepared as a solution of sodium chloride $(\mathrm{NaCl})$, sodium bicarbonate $\left(\mathrm{NaHCO}_{3}\right)$ and calcium carbonate $\left(\mathrm{CaCO}_{3}\right)$, which are all the degree of purity of Pro Analysis by Sigma Aldrich. For each electrochemical measurement conducted, one litre of fresh solution was prepared, with or without the addition of different concentrations of plant extracts as corrosion inhibitors. The chemical composition of the simulated brine solution is given in Table 3 .

For preliminary research, ten plant extracts were chosen:

- Punica granatum (pomegranate) (seeds, fruit, peel),

- Melissa officinalis (lemon balm) leaves,
Table 3: Chemical composition of the simulated brine solution

\begin{tabular}{|l|c|}
\hline Chemical compound & $\gamma(\mathbf{g} / \mathbf{L})$ \\
\hline $\mathrm{NaCl}$ & 30.0 \\
\hline $\mathrm{NaHCO}_{3}$ & 0.1 \\
\hline $\mathrm{CaCO}_{3}$ & 0.1 \\
\hline
\end{tabular}

- Vitis vinifera, Vitis (grape pomace),

- Taraxacum officinale (dandelion) root,

- Passiflora incarnata L. (passionflower) (leaves and flowers),

- Arctium lappa L. (burdock) root,

- Glycyrrhizma glabra L. (liquorice) root,

- Crataegus oxyacantha (hawthorn) (leaves and flowers),

- Sempervivum tectorum L. (houseleek),

- Alchemilla vulgaris (lady's mantle) leaves.

The plant extracts were added to the brine solution in various concentrations, varying from $100 \mathrm{mg} / \mathrm{L}$ to even $20000 \mathrm{mg} / \mathrm{L}$, based on the available literature on the previously conducted research. Before every measurement, the prepared solution was saturated with carbon dioxide for 45 minutes, and continuously stirred at 300 rpm during electrochemical measurement. Measurements were conducted at room temperature. The experiments were conducted by using three-electrode corro-

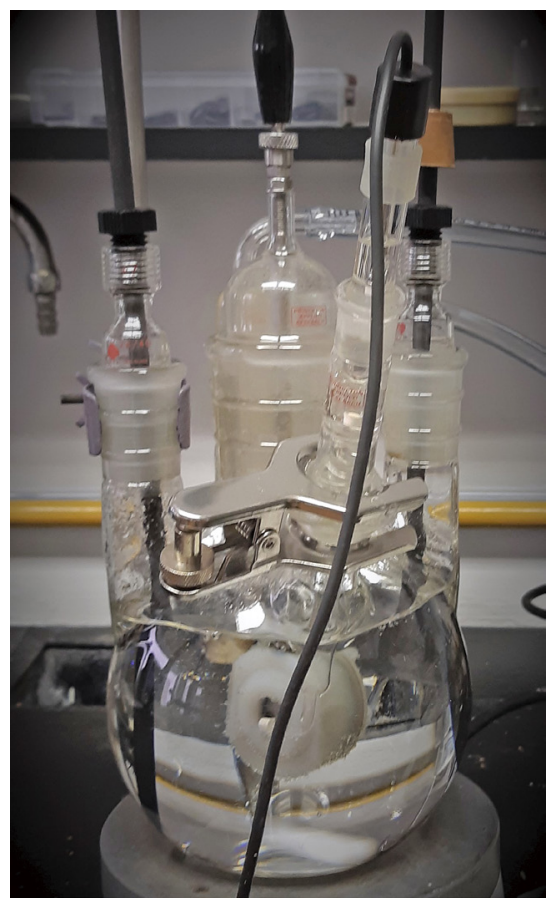

Figure 1: Three electrode corrosion cell 


\section{Pomegranate}

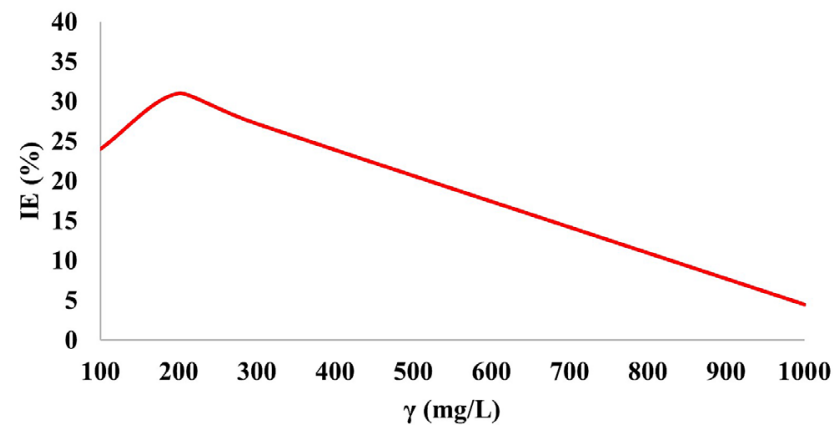

Figure 2: Inhibitor efficiency of pomegranate

Lemon balm

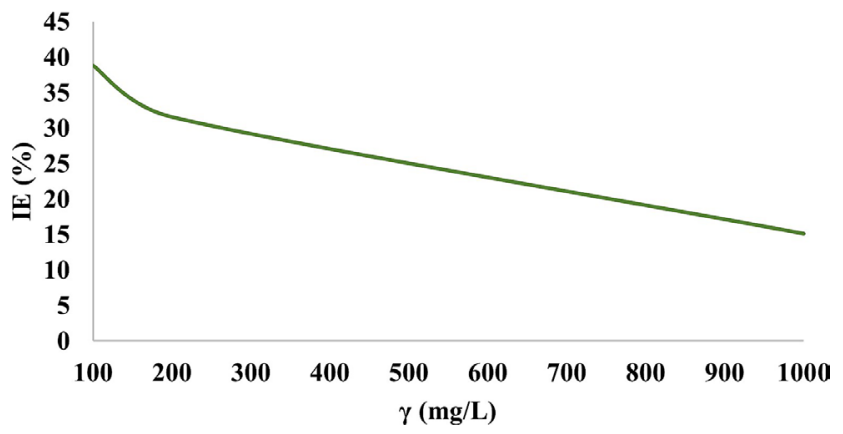

Figure 3: Inhibitor efficiency of lemon balm

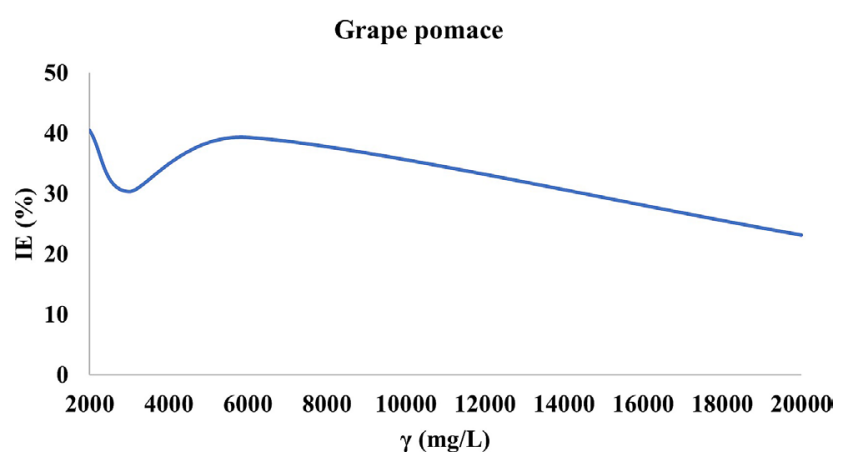

Figure 4: Inhibitor efficiency of grape pomace

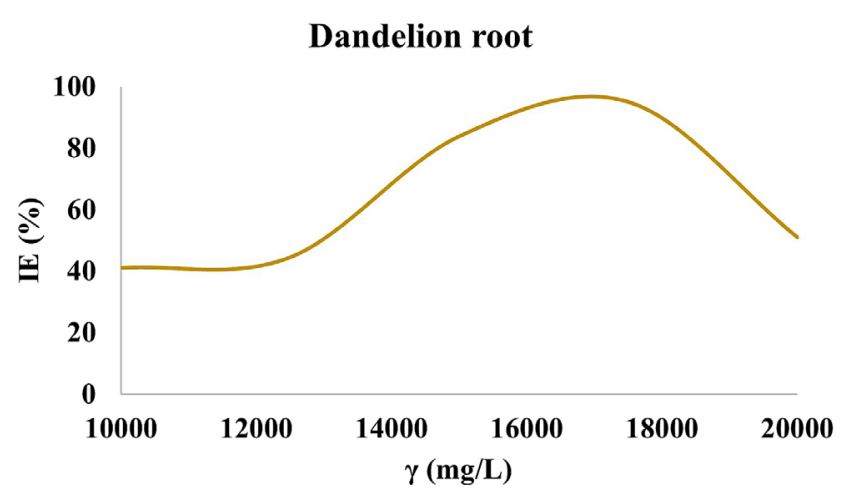

Figure 5: Inhibitor efficiency of dandelion root

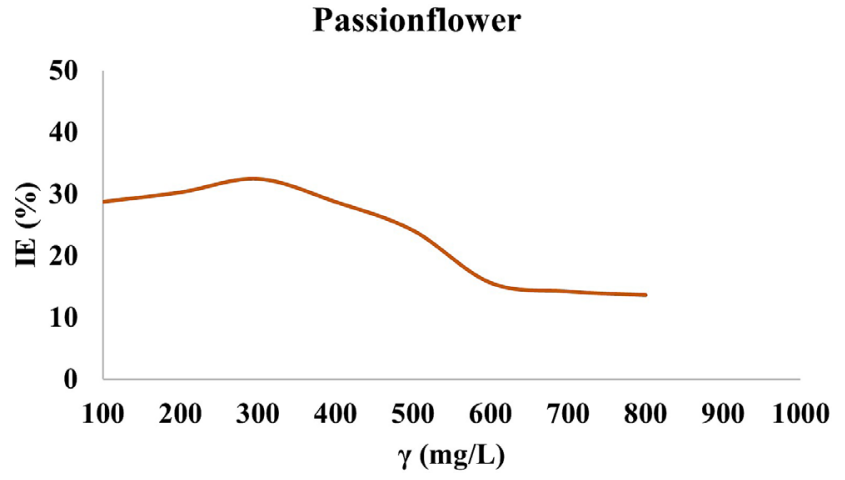

Figure 6: Inhibitor efficiency of passionflower

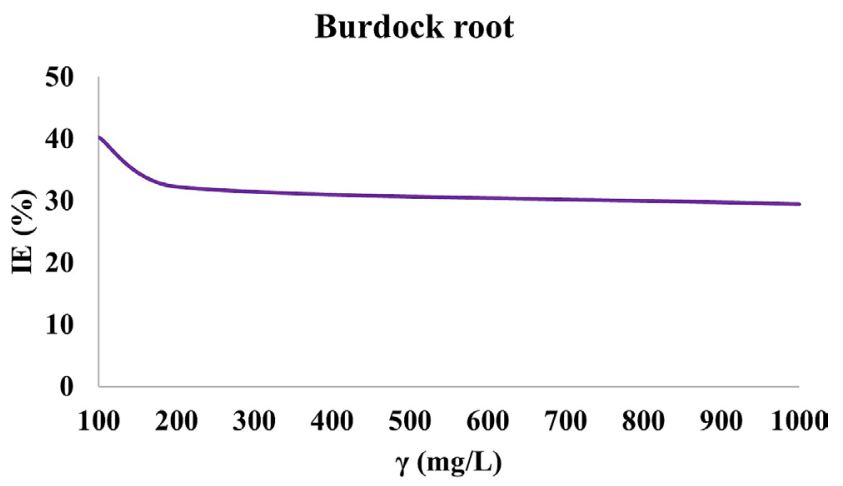

Figure 7: Inhibitor efficiency of burdock root

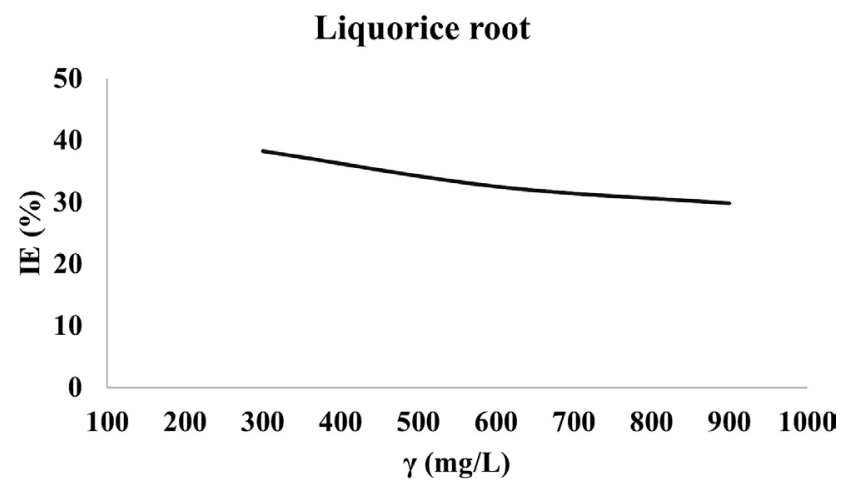

Figure 8: Inhibitor efficiency of liquorice root

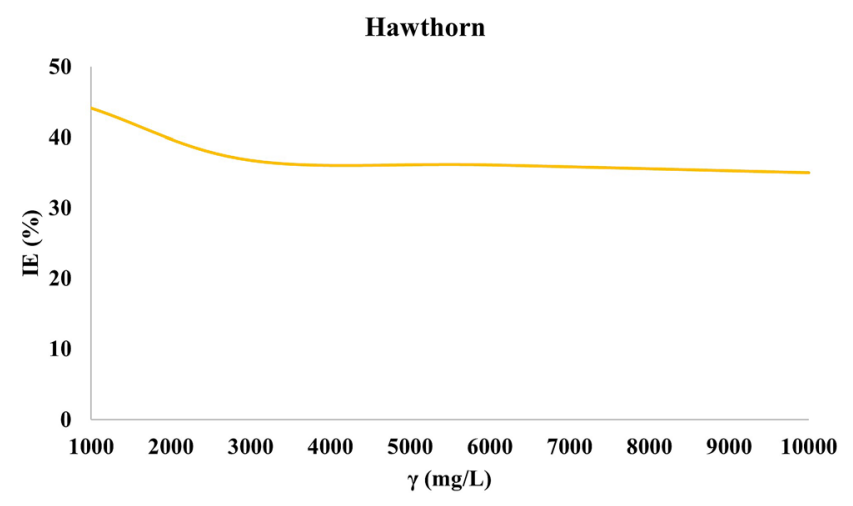

Figure 9: Inhibitor efficiency of hawthorn 
Houseleek

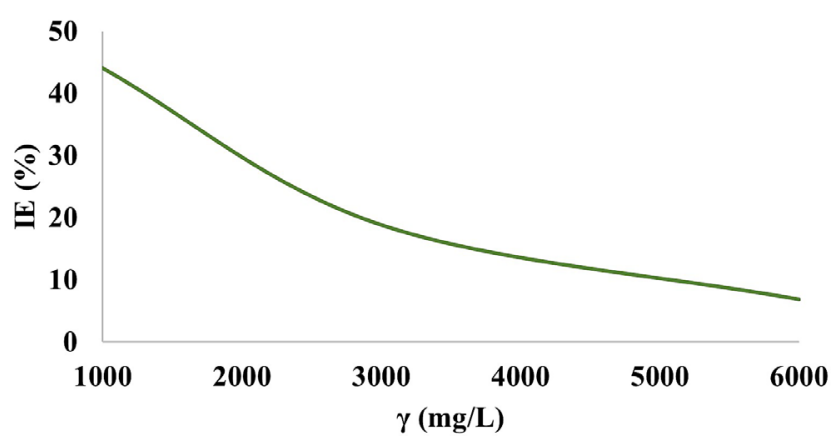

Figure 10: Inhibitor efficiency of houseleek

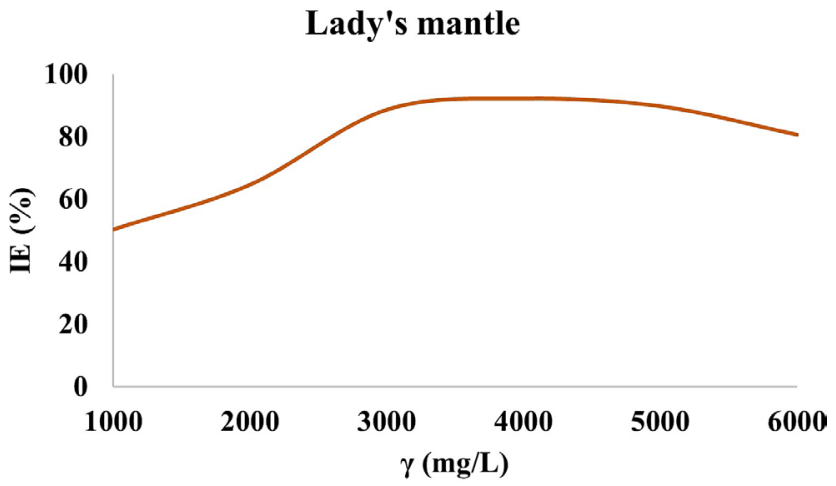

Figure 11: Inhibitor efficiency of lady's mantle

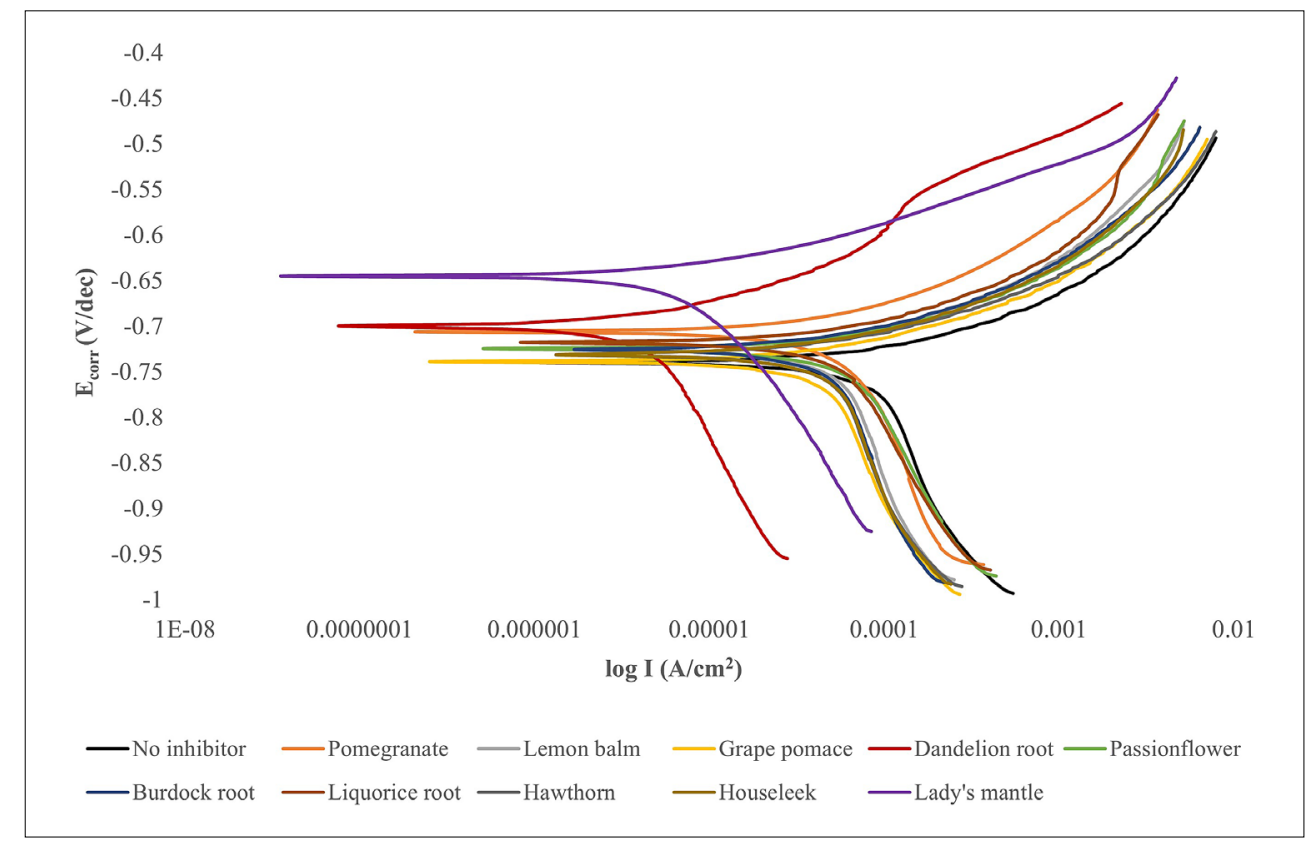

Figure 12: Tafel polarization curves for steel sample in brine solution saturated with $\mathrm{CO}_{2}$, without and with the most efficient concentration of different plant extracts

Table 4: Electrochemical parameters for steel sample in brine solution saturated with $\mathrm{CO}_{2}$, with and without the most efficient concentration of different plant extracts

\begin{tabular}{|l|l|l|l|l|l|l|}
\hline & $\boldsymbol{\gamma}(\mathbf{m g} / \mathbf{L})$ & $\boldsymbol{E}_{\boldsymbol{k} \boldsymbol{r}}(\mathbf{m V})$ & $\boldsymbol{j}_{\boldsymbol{k} \text { or }}\left(\boldsymbol{\mu} \mathbf{A} / \mathbf{c m}^{2}\right)$ & $-\boldsymbol{\beta}_{\boldsymbol{k}}(\mathbf{V} / \mathbf{d e c})$ & $\boldsymbol{\beta}_{\boldsymbol{a}}(\mathbf{V} / \mathbf{d e c})$ & $\boldsymbol{v}_{\boldsymbol{k} \text { or }}(\mathbf{m m} / \mathbf{y})$ \\
\hline No inhibitor & - & -741 & 97.627 & 0.517 & 0.065 & 1.136 \\
\hline Pomegranate & 200 & -708 & 67.351 & 0.413 & 0.093 & 0.784 \\
\hline Lemon balm & 100 & -725 & 59.702 & 0.469 & 0.068 & 0.695 \\
\hline Grape pomace & 1000 & -738 & 50.880 & 0.459 & 0.060 & 0.592 \\
\hline Dandelion root & 17500 & -699 & 4.809 & 0.324 & 0.062 & 0.056 \\
\hline Passionflower & 300 & -726 & 65.918 & 0.365 & 0.063 & 0.767 \\
\hline Burdock root & 100 & -726 & 58.372 & 0.535 & 0.068 & 0.679 \\
\hline Liquorice root & 300 & -720 & 60.312 & 0.348 & 0.071 & 0.702 \\
\hline Hawthorn & 1000 & -732 & 54.540 & 0.494 & 0.061 & 0.635 \\
\hline Houseleek & 1000 & -732 & 54.581 & 0.419 & 0.067 & 0.635 \\
\hline Lady's mantle & 4000 & -663 & 7.690 & 0.172 & 0.037 & 0.09 \\
\hline
\end{tabular}




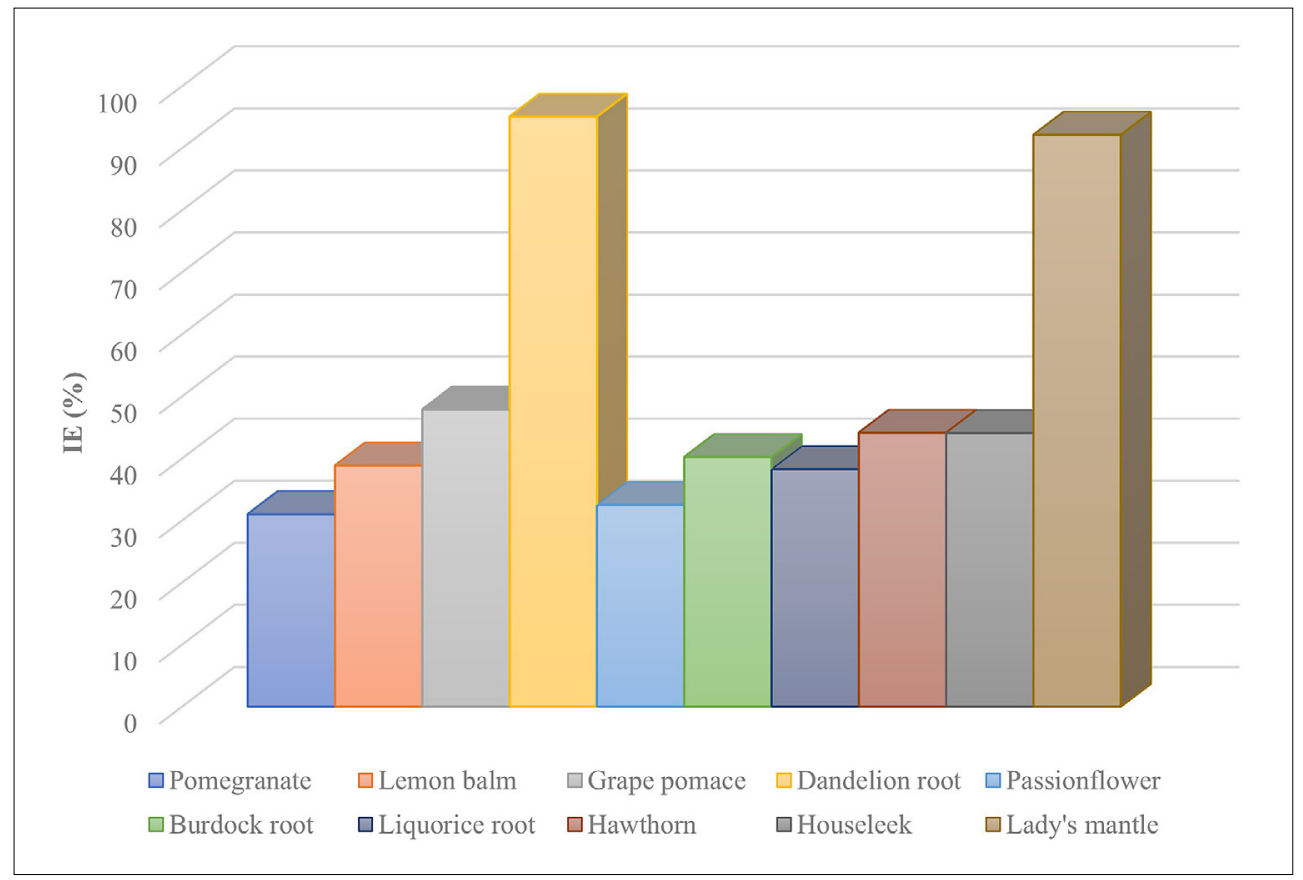

Figure 13: Highest corrosion inhibitor efficiency of each plant extract

Table 5: Highest corrosion inhibitor efficiency of each plant extract with corresponding concentration

\begin{tabular}{|l|l|l|}
\hline Plant extract & $\boldsymbol{\gamma}(\mathbf{m g} / \mathbf{L})$ & Highest IE (\%) \\
\hline Pomegranate & 200 & 31 \\
\hline Lemon balm & 100 & 38.84 \\
\hline Grape pomace & 1000 & 47.88 \\
\hline Dandelion root & 17500 & 95.07 \\
\hline Passionflower & 300 & 32.47 \\
\hline Burdock root & 100 & 40.2 \\
\hline Liquorice & 300 & 38.22 \\
\hline Hawthorn & 1000 & 44.13 \\
\hline Houseleek & 1000 & 44.09 \\
\hline Lady's mantle & 4000 & 92.12 \\
\hline
\end{tabular}

sion cells (shown in Figure 1). The carbon steel sample was used as the working electrode, with $1 \mathrm{~cm}^{2}$ area exposed to the brine solution. Before every measurement, the carbon steel sample was sanded with 360, 600 and 1200 grit paper, washed with distilled water and degreased with $96 \%$ ethanol. Two graphite rods were used as the counter electrode and a saturated calomel electrode as the reference electrode.

All measurements were performed using an SP1 potentiostat and SmartManger software with IVMAN programme for analysing data. Prior to polarization measurement, the working electrode was stabilised at open circuit potential for 1 hour. For Tafel polarization curves, the corrosion potential was set to $\pm 250 \mathrm{mV}$ versus open circuit potential with a scan rate of $0.166 \mathrm{mV} / \mathrm{s}$. For determining the corrosion rate and inhibition efficiency of various concentrations of plant extracts, polarization measurements (with Tafel extrapolation) were performed. Each measurement was repeated three times for reproducibility.

\section{Results and discussion}

In order to examine the inhibitory activity and determine the concentrations of the extracts at which they show the highest effectiveness, potentiodynamic polarization by Tafel extrapolation was performed. Polarization curves were recorded for all the mentioned extracts in a certain range of concentrations. However, due to the large number of tested extracts, as well as better visibility of the results, all scanned polarization curves are not shown, but rather the graphical dependence of inhibitor efficiency (IE) on extract concentration $(\gamma$ ) (see Figure 2 to Figure 11). Inhibitor efficiency can be calculated as shown in Equation 1 (Sastri, 2011):

$$
I E(\%)=\frac{v_{k o r}^{o}-v_{k o r}^{i n h}}{v_{k o r}^{o}} \times 100 \#
$$

Where:

IE - inhibitor efficiency (\%),

$v_{k o r}{ }^{o}$ - corrosion rate in solution without inhibitor (mm/year),

$v_{\text {kor }}{ }^{i n h}$ - corrosion rate in solution with inhibitor $(\mathrm{mm} /$ year).

As can be seen from Figures 2 to 11, for most of the tested plant extracts, the corrosion inhibitor efficiency was around $40 \%$, but lady's mantle and dandelion root stood out with an inhibitor efficiency of more than $90 \%$. Tafel polarization curves for the most efficient concentration of each plant extract in comparison with the brine 
solution without an inhibitor is shown in Figure 12. Electrochemical parameters determined from Tafel extrapolation are listed in Table 4.

It can be seen from Table 4 that with each tested plant extract, the corrosion potential $\left(E_{k o r}\right)$ has moved towards positive values, which could indicate the formation of a protective film on the steel surface. The change in corrosion potential was below $85 \mathrm{mV}$. Also, for all plant extracts, there is a decrease in corrosion current density $\left(j_{k o r}\right)$ which indicates lower corrosion rates. The presence of plant extract in the simulated brine solution, in the case of all plant extracts, except burdock root extract, results in a decrease of the value of the cathodic Tafel slope $\left(\boldsymbol{\beta}_{k}\right)$, which points to a diminishing effect of diffusion on the cathodic process (Equation 2):

$$
2 \mathrm{H}^{+}+2 e^{-} \rightarrow \mathrm{H}_{2} \#
$$

Regarding anodic Tafel slopes $\left(\boldsymbol{\beta}_{a}\right)$, there is a small change in values in brine solutions containing plant extracts. This could be a sign of inhibitor blocking active sites preventing a reaction to occur. Taking everything stated into consideration, it can be concluded that the researched plant extracts are behaving as mixed-type corrosion inhibitors for low carbon steel in a brine solution saturated with $\mathrm{CO}_{2}$, thus slowing down both corrosion reactions with a main influence on the anode process (Equation 3):

$$
\mathrm{Fe} \rightarrow \mathrm{Fe}^{2+}+2 e^{-} \#
$$

The highest corrosion inhibition efficiency of each plant extract is shown in Figure 13. A list of the plant extracts with corresponding concentrations at which the highest efficiency is achieved is given in Table $\mathbf{5}$.

According to Figure 13 and Table 5, two plant extracts stood out - dandelion root (inhibitor efficiency of $95.07 \%$ at a concentration of $17500 \mathrm{mg} / \mathrm{L}$ ) and lady's mantle (inhibitor efficiency of $92.12 \%$ at a concentration of $4000 \mathrm{mg} / \mathrm{L}$ ). To get a better insight in their behaviour and adsorption on a metal surface, further electrochemical and surface analysis research will be conducted.

\section{Conclusions}

In this paper, a review of previously conducted laboratory research of green inhibitors' efficiency is shown, as well as the results of the laboratory research of some plant extracts that can be found in Croatia. The plant extracts were studied as potential inhibitors of carbon steel corrosion in a simulated brine solution saturated with $\mathrm{CO}_{2}$. The aim of this study was to isolate extracts of high inhibitor efficiency (more than 90\%), which, if their effectiveness was confirmed by subsequent tests, could be successfully applied in the protection of carbon steel in hydrocarbon production and transportation systems in Croatia. The study showed a significant decrease of cor- rosion rate in the cases of the dandelion root extract $(0,056 \mathrm{~mm} / \mathrm{y})$ and the lady's mantle extract $(0.09 \mathrm{~mm} / \mathrm{y}))$ compared to the uninhibited system $(1.136 \mathrm{~mm} / \mathrm{y})$. Potentiodynamic polarization with Tafel extrapolation determined inhibitor efficiencies of $92.17 \%$ for the lady's mantle extract at a concentration of $4000 \mathrm{mg} / \mathrm{L}$, and $95.07 \%$ for the dandelion root extract at a concentration of $17500 \mathrm{mg} / \mathrm{L}$. Both tested extracts showed a small change in corrosion potential compared to the uninhibited system (less than $85 \mathrm{mV}$ ), which points out to their behaviour as mixed-type inhibitors, as retarding both anodic and cathodic corrosion reactions.

The mentioned extracts, that showed the best inhibitor efficiency (the dandelion root extract and the lady's mantle extract), will be further tested by electrochemical impedance spectroscopy (EIS), and surface methods (FTIR - Fourier-transform infrared spectroscopy and SEM - Scanning electron microscopy) to determine their mechanism of action under the test conditions. The same measurements will be conducted in dynamic conditions. To examine the effect of the chosen plant extracts on the environment, biodegradability and toxicity tests will be performed.

\section{Acknowledgment}

This paper was compiled within the University Project GreenInh (no. 311980012).

\section{References}

Ahmed, R.K., Zhang, S. (2019): Alchemilla Vulgaris Extract as Green Inhibitor of Copper Corrosion in Hydrochloric Acid, International Journal of Electrochemical Science, 14, 10657-10669. DOI: 10.20964/2019.11.43

Alibakhshi, E., Ramezanzadeh, M., Haddadi, S.A., Bahlakeh, G., Ramezanzadeh, B., Mahdavian, M. (2018.): Persian Liquorice extract as a highly efficient sustainable corrosion inhibitor for mild steel in sodium chloride solution, Journal of Cleaner Production, 210, 660-670. DOI: 10.1016/j.jclepro.2018.11.053

Byars, H. G. (1999): Corrosion Control in Petroleum Production, NACE, Houston, 233 p.

Bouammali, H., Ousslim, A., Bekkouch, K., Bouammali, B., Aouniti, A., Al-Deyab, S.S., Jama, C., Bentiss, F., Hammouti, B. (2013): The Anti-Corrosion Behavior of Lavandula dentata Aqueous Extract on Mild Steel in $1 \mathrm{M}$ $\mathrm{HCl}$, International Journal of Electrochemical Science, 8, 6005-6013.

Bozorg, M., Farahani, T.S., Neshati, J., Chaghazardi, Z., Ziarani, G.M. (2014): Myrtus Communis as Green Inhibitor of Copper Corrosion in Sulfuric Acid, Industrial \& Engineering Chemistry Research, 53, 4295-4303. DOI: 10.1021/ ie 404056w

Cech, M., Davis, P., Guijt, W., Haskamp, A., Huidobro Barrio, I. (2021): Performance of European cross-country oil pipelines Statistical summary of reported spillages in 2019 and since 1971, Report. Brussels, 4/21 
Cordeiro, R.F.B., Belati, A.J.S., Perrone, D., D’elia, E (2018): Coffee Husk as Corrosion Inhibitor for Mild Steel in $\mathrm{HCl}$ Media, International Journal of Electrochemical Science, 13, 12188-12207. DOI: 10.20964/2018.12.29

Da Rocha, J.C., Ponciano Gomes, J.A.C., D’elia, E., Gil Cruz, A.P., Cabral, L.M.C., Torres, A.G., Monteiro, M.V.C. (2012): Grape Pomace Extracts as Green Corrosion Inhibitors for Carbon Steel in Hydrochloric Acid Solutions, International Journal of Electrochemical Science, 7, 1194111956.

Dehghani, A., Blahlakeh, G., Ramezanzadeh, B., Ramezanzadeh, M. (2019): A combined experimental and theoretical study of green corrosion inhibition of mild steel in $\mathrm{HCl}$ solution by aqueous Citrullus lanatus fruit (CLF) extract, Journal of Molecular Liquids, 279, 603-624. DOI: 10.1016/j.molliq.2019.02.010

Devikala, S., Kamaraj, P., Arthanareeswari, M., Patel, M.B. (2019a): Green corrosion inhibition of mild steel by aqueous Allium sativum extract in $3.5 \% \mathrm{NaCl}$, Materials Today: Proceedings 14, 580-589. DOI: 10.1016/J.MATPR.2019.04.182

Devikala, S., Kamaraj, P., Arthanareeswari, M., Patel, M.B. (2019b): Green corrosion inhibition of mild steel by Asafoetida extract in $3.5 \% \mathrm{NaCl}$, Materials Today: Proceedings 14, 590-601. DOI: 10.1016/j.matpr.2019.04.183

Deyab, M.A., Guibal, E. (2020): Enhancement of corrosion resistance of the cooling systems in desalination plants by green inhibitor, Scientific Reports, 10:4812. DOI: 10.1038/ s41598-020-61810-9

Flores-De los Ríos J. P., Sánchez-Carrillo M., Nava-Dino C. G., Chacón-Nava J. G., González-Rodríguez J. G., HuapePadilla E., Neri-Flores M. A., Martínez-Villafañe A. (2015): Opuntia ficus-indica Extract as Green Corrosion Inhibitor for Carbon Steel in $1 \mathrm{M} \mathrm{HCl} \mathrm{Solution,} \mathrm{Journal} \mathrm{of}$ Spectroscopy, vol. 2015, Article ID 714692, 9 p. DOI: $10.1155 / 2015 / 714692$

Fouda, A.S., El-Awady, G.Y., El Behairy, W.T. (2018): Prosopis juliflora Plant Extract as Potential Corrosion Inhibitor for Low-Carbon Steel in $1 \mathrm{M} \mathrm{HCl} \mathrm{Solution,} \mathrm{Journal} \mathrm{of}$ Bio- and Tribo-Corrosion, 4:8. DOI:10.1007/s40735-0170124-x

Garai, S., Garai S., Jaisankar, P., Singh, J.K., Elango, A. (2012): A comprehensive study on crude methanolic extract of Artemisia pallens (Asteraceae) and its active component as effective corrosion inhibitors of mild steel in acid solution. Corrosion Science, 60, 193-204. DOI: 10.1016/j.corsci.2012.03.036

Goni, L.K.M.O., Mazumder, M.A.J. (2019): Green Corrosion Inhibitors, In: Singh, A., (eds.), Corrosion Inhibitors, IntechOpen

Grlić, Lj. (1990): Enciklopedija samoniklog jestivog bilja, 2nd edition, Zagreb: August Cesarec (in Croatian), 392 p.

Hossain, N., Chowdhury, M.A., Parvez Iqbal, A.K.M., Sariful Islam, Md., Sheikh Omar, N.Y. (2021): Paederia Foetida Leaves Extract as a Green Corrosion Inhibitor for Mild Steel in Hydrochloric Acid Solution. 21 p. dx.doi. org/10.2139/ssrn.3901831

Ina d.d. (2021): Tehnička dokumentacija o propuštanjima cjevovoda
Ji, G., Shukla, S.K., Ebenso, E.E., Prakash, R. (2013): Argemone mexicana Leaf Extract for Inhibition of Mild Steel Corrosion in Sulfuric Acid Solutions, International Journal of Electrochemical Science, 8, 10878-10889.

Khadom, A.A., Abd, A.N., Ahmed, N.A. (2018): Xanthium strumarium leaves extracts as a friendly corrosion inhibitor of low carbon steel in hydrochloric acid: Kinetics and mathematical studies, South African Journal of Chemical Engineering, 25, 13-21. DOI: 10.1016/j.sajce.2017.11.002

Koch, G., Varney, J., Thompson, N., Moghissi, O., Gould, M., Payer, J. (2016): International Measures and Prevention, Application and Economics of Corrosion Technologies Study, Report, NACE International, Houston

Li, L., Zhang, X., Lei, J., He, J., Zhang, S., Pan, F. (2012): Adsorption and corrosion inhibition of Osmanthus fragrans leaves extract on carbon steel. Corrosion Science, 63, 82-90. DOI:10.1016/j.corsci.2012.05.026

Montemor M.F. (2016): Fostering Green Inhibitors for Corrosion Prevention. In: Hughes A., Mol J., Zheludkevich M., Buchheit R. (eds.) Active Protective Coatings. Springer Series in Materials Science, 233, 107-137, Springer, Dordrecht. DOI: 10.1007/978-94-017-7540-3_6

Mourya, P., Banerjee, S., Singh, M.M. (2014): Corrosion inhibition of mild steel in acidic solution by Tagetes erecta (Marigold flower) extract as a green inhibitor, Corrosion Science, 85, 352-363. DOI: 10.1016/j.corsci.2014.04.036

Nešić, S. (2011): Carbon Dioxide Corrosion of Mild Steel, In: Revie, R.W., (eds.), Uhlig's Corrosion Handbook, Third Edition, New Jersey, John Wiley \& Sons, Inc., 229-245.

Olawale, O., Adediran, A.A., Oyinbo, T., Kalawole, O. (2017): Inhibitory action of rice husk extract (RHE) on the corrosion of carbon steel in acidic media, Aceh International Journal of Science and Technology, 6(2), 44-51. DOI:10.13170/aijst.6.2.8456

Popoola, L.T. (2019): Organic green corrosion inhibitors (OGCIs): a critical review, Corrosion Reviews, 37(2), 71-102. DOI:10.1515/corrrev-2018-0058

Pustaj, G., Kapor, F., Jakovljević, S. (2017): Carbon dioxide corrosion of carbon steel and corrosion inhibition by natural olive leaf extract. Materialwissenschaft und Werkstofftechnik, 48 (2), 122-138. DOI: 10.1002/mawe.2016 00598

Qiang, Y., Zhang, S., Tan, B., Chen, S. (2018): Evaluation of Ginkgo leaf extract as an eco-friendly corrosion inhibitor of X70 steel in $\mathrm{HCl}$ solution, Corrosion Science, 133, 6-16. DOI:10.1016/j.corsci.2018.01.008

Saeed, M.T., Saleem, M., Niyazi, A.H., Al-Shamrani, F.,A., Jazzar, N.A., Ali, M. (2020): Carrot (Daucus Carota L.) Peels Extract as an Herbal Corrosion Inhibitor for Mild Steel in 1M HCl Solution, Modern Applied Science, 14 (2), 97-112. DOI:10.5539/mas.v14n2p97

Sastri, V. S. (2011): Green Corrosion Inhibitors: Theory and Practice, Hoboken, New Jersey, John Wiley \& Sons, Inc., $328 \mathrm{p}$.

Saxena, A., Prasad, D., Haldhar, R., Singh, G., Kumar, A. (2018a): Use of Saraca ashoka extract as green corrosion inhibitor for mild steel in $0.5 \mathrm{M} \mathrm{H} 2 \mathrm{SO} 4$, Journal of Molecular Liquids, 258, 89-97. DOI:10.1016/j.molliq. 2018.02.104 
Saxena, A., Prasad, D., Haldhar, R., Singh, G., Kumar, A. (2018b): Use of Sida cordifolia extract as green corrosion inhibitor for mild steel in $0.5 \mathrm{M} \mathrm{H} 2 \mathrm{SO} 4$, Journal of Environmental Chemical Engineering, 6(1), 694-700. DOI: 10.1016/j.jece.2017.12.064

Shah, A.M., Rahim, A.A., Hamid, S.A., Yahya, S. (2013): Green Inhibitors for Copper Corrosion by Mangrove Tannin, International Journal of Electrochemical Science, 8, 2140-2153.
Shehata, O.S., Korshed, L.A., Attia, A. (2018.): Green Corrosion Inhibitors, Past, Present and Future, In: Aliofkhazraei, M., (eds.), Corrosion Inhibitors, Principles and Recent Applications, IntechOpen, 121-142

Ugi, B.U., Obeten, M.E., Magu, T.O. (2018): Phytochemical constituents of Taraxacum officinale leaves as eco-friendly and nontoxic organic inhibitors for stainless steel corrosion in $0.2 \mathrm{M} \mathrm{HCl}$ acid Medium, International Journal of Chemical Science, 2 (6), 35-43.

\section{SAŽETAK}

\section{Mogućnost primjene biljnih ekstrakata kao zelenih inhibitora korozije u naftnoj industriji}

U ovome radu provedena su preliminarna ispitivanja deset različitih biljnih ekstrakata kao potencijalnih korozijskih inhibitora ugljičnoga čelika. Za svaki ekstrakt najprije je određen raspon koncentracija u kojemu pokazuje antikorozijsko djelovanje, a potom je za svaki ekstrakt određena najdjelotvornija koncentracija. Ispitivanja su provedena u sintetskoj slojnoj vodi zasićenoj $\mathrm{s} \mathrm{CO}_{2}$ pri sobnoj temperaturi. Cilj rada bio je izdvojiti ekstrakte s visokim djelotvornostima te naknadnim elektrokemijskim i površinskim metodama utvrditi mehanizam inhibitorskoga djelovanja. U tu svrhu provedena je potenciodinamička polarizacija s Tafelovom ekstrapolacijom. Od svih ispitanih ekstrakata sa svojim djelotvornostima izdvajaju se vrkuta $(92,17 \%)$ i korijen maslačka $(95,07 \%)$. Oba ispitana ekstrakta pokazala su ponašanje mješovitoga korozijskog inhibitora s dominantnim utjecajem na anodni proces.

\section{Ključne riječi:}

$\mathrm{CO}_{2}$ korozija, naftna industrija, ugljični čelik, biljni ekstrakti, zeleni inhibitori korozije

\section{Author's contribution}

This paper is a part of the PhD research of the author Katarina Žbulj ( $\mathrm{PhD}$ student, graduate engineer of petroleum engineering) who initialized the idea, lead the laboratory research, and participated in the interpretation of the laboratory results. The supervisor of the PhD thesis, Gordana Bilić (PhD, Assistant Professor) participated in the determination of research methods, supervised laboratory research, participated in the interpretation of the results, in the discussion of the results and made a critical revision of the paper. The supervisor of the PhD thesis, Lidia Hrnčević (PhD, Associate Professor) participated in the interpretation of the results, in the discussion of the results and made a critical revision of the paper. Katarina Simon (PhD, Full Professor) participated in the interpretation of the results, in the discussion of the results and made a critical revision of the paper. All the authors participated in writing the paper, as well as defining future research. 